\title{
Covid-19, complexidade dos fatos e suspensão de obrigações tributárias pelo Poder Judiciário
}

\author{
Covid-19, complexity of the facts and suspension of tax obligations \\ by the Judiciary
}

Renato Lopes Becho ${ }^{1}$

Roberto Lima Campelo ${ }^{2}$

\begin{abstract}
RESUMO
O objetivo deste artigo é apresentar os motivos de ordem política, fática e jurídica que impedem que o Poder Judiciário conceda causas de suspensão do crédito tributário em face dos impactos econômicos causados a diversos contribuintes em decorrência da pandemia gerada pelo vírus COVID-19. A partir da apresentação de um caso concreto recorrente que chegou à apreciação do Poder Judiciário, qual seja, ações judiciais que veiculam pedido de suspensão das obrigações tributárias principais, sob fundamento de incidência de norma jurídica não relacionada à pandemia causada pelo vírus COVID-19 -, são expostos os limites políticos, operacionais e jurídicos que impedem que o Poder Judiciário conceda a tutela pretendida, particularmente a separação dos poderes e a complexidade do caso, que exige um tratamento sistemático e uniforme por parte do Poder Legislativo.
\end{abstract}

PALAVRAS-CHAVE:

Direito Tributário, Causa de suspensão do crédito tributário, Poder Judiciário, Decisão judicial, COVID-19, Crise econômica.

\begin{abstract}
The aim of this article is to present the political, factual and legal reasons that prevent the Judiciary from granting causes for suspension of the tax credit in view of the economic impacts caused by the various taxpayers due to the pandemic generated by the COVID-19 virus. From the presentation of a specific recurring case that is brought to the Judiciary, that is, lawsuits that convey a request for suspension of the main tax obligations on the grounds of incidence of a legal rule unrelated to the pandemic caused by the COVID-19 virus, are exposed the political, operational and legal limits that prevent the Judiciary from granting the desired protection, particularly the separation of powers and the complexity of the case, which requires systematic and uniform treatment by the Legislative Branch.
\end{abstract}

\section{KEYWORDS:}

Tax Law, Cause of suspension of the tax credit, Judicial power, Judicial decision, COVID-19, Economic crisis.

\footnotetext{
${ }^{1}$ Doutor, Mestre e Professor de Direito Tributário na Pontifícia Universidade Católica de São Paulo (PUC-SP). Livre-docente em Direito Tributário pela Universidade de São Paulo (USP). Estágio pós-doutoral no King's College de Londres. Juiz federal em São Paulo/SP. E-mails: renatobecho@uol.com.br e rbecho@pucsp.br

${ }^{2}$ Mestrando em Direito na Pontifícia Universidade Católica de São Paulo (PUC-SP). Juiz federal em São Paulo. E-mail: robertolcampelo@gmail.com.
} 


\section{INTRODUÇÃO}

A pandemia causada pelo COVID-19 impactou a economia global de maneira intensa. A redução da oferta e da demanda mundial atingiram rapidamente o fluxo de caixa das empresas, principalmente aquelas que possuíam reduzida margem para operar por um período de tempo razoável sem entrar em endividamento.

Diversas incertezas científicas circulam em torno do tema, principalmente pelo fato do vírus revelar uma dinâmica consideravelmente distinta das demais espécies do gênero corona. A ausência de um tratamento e de uma vacina forçam os governos a tomarem medidas de isolamento social para reduzir as taxas de transmissão do vírus e do índice de óbitos que crescem em progressão geométrica e que, ao mesmo tempo, afetam as diversas atividades econômicas em diferentes graus.

Por conta das dificuldades financeiras, diversos contribuintes recorreram ao Poder Judiciário pleiteando uma tutela jurisdicional que permitisse a suspensão do pagamento dos tributos federais sob o fundamento da incidência da Portaria $\mathrm{n}^{\mathrm{o}} 12$ do Ministério da Fazenda, de 10/01/2012, à pandemia que assola atualmente o mundo inteiro. Pretende-se, assim, utilizar uma legislação anterior ao caso, conferindo-lhe os mesmos efeitos outrora concedidos.

Os pedidos foram protocolados perante inúmeros órgãos de primeiro grau da Justiça Federal, gerando decisões favoráveis e contrárias ao pedido.

O tema, aparentemente restrito à interpretação de uma norma infra legal, revela a problemática da atuação do Poder Judiciário em cenários de crise e levanta questionamentos acerca da melhor postura a ser adotada pelo juiz que, ao mesmo tempo que deve levar em consideração a complexidade do caso, deve decidir em conformidade com as balizas do Estado de Direito. 


\section{JUÍZES E LEGISLADORES}

Lorde Devlin, ex-juiz da High Court of Justice, ${ }^{3}$ em 1976, pontuou que o serviço social que o juiz presta à comunidade é o de remover o senso de injustiça e que, para realizar essa missão, é essencial a imparcialidade e a aparência de imparcialidade do juiz, porque de nada bastaria ter toda a técnica da tomada de decisão se o juiz não se mostra imparcial. ${ }^{4}$ Entretanto, segundo Devlin, o objeto do processo não seria submeter as partes a uma forma de argumentação superior, mas prover um método civilizado de solucionar os conflitos, ${ }^{5}$ o que, na prática, significa remover das partes o senso de injustiça que ocorre, não necessariamente quando se tem um direito violado, mas quando não há meios para desafiar o ofensor do direito, restando tão somente a submissão. ${ }^{6}$

Para Devlin, a imparcialidade do juiz é determinada pela aderência judicial à lei e assevera que, se o juiz deixa o que está escrito na lei e toma suas próprias decisões, ainda que materialmente justas, ele perde a proteção da lei e sacrifica a aparência da imparcialidade. ${ }^{7}$

Devlin define caminhos absolutamente distintos entre a política e o Direito, sendo este o instrumento para apoiar aquela, dependendo do consenso que se estabelece sobre determinada questão. O papel do juiz é o de respeitar o consenso, desde que plasmado pelo Direito:

\footnotetext{
Novas políticas devem ganhar força antes de poderem forçar uma entrada: quando são admitidas e absorvidas no consenso, o sistema legal deve se expandir para mantê-los, como também deveria se contrair para expulsar do sistema políticas antigas que perderam o consenso que obtiveram outrora. ${ }^{8}$
}

Nesse sentido, segundo Lorde Devlin, a atitude do juiz depende do enfrentamento de três termos por ele mesmo definidos: consenso, legislação dinâmica ou criativa e legislação ativista. Consenso é o conjunto de ideias com as quais se concorda ou mesmo com as quais se discorda, mas que são obedecidas por uma comunidade por uma dada razão, ${ }^{9}$ como, por

\footnotetext{
${ }^{3}$ A High Court of Justice, sediada em Londres, tem competência originária, para casos de grande valor, e competência revisional das decisões de cortes inferiores, tendo jurisdição em todo o Reino Unido.

${ }^{4}$ DEVLIN, Patrick Arthur. Judges and Lawmakers. In Modern Law Review, 39, 1976, p. 3.

${ }^{5}$ Idem, p. 3.

${ }^{6}$ Ibidem, p. 3.

${ }^{7}$ Ibidem, p. 1.

${ }^{8}$ Ibidem, p. 1.

${ }^{9}$ Ibidem, p. 2.
} 
exemplo, em troca de uma vida pacífica em sociedade, é aceitável a convivência com uma pluralidade de crenças e deveres. Por sua vez, a legislação ativista seria aquela que acompanha o ritmo das mudanças do consenso. ${ }^{10}$ Por fim, legislação dinâmica ou criativa é aquela que usa a lei para promover mudanças no próprio consenso ${ }^{11} \mathrm{e}$, nesse caso, aquele tomador de decisão deve não apenas ser simpático às novas ideias, mas um verdadeiro entusiasta delas. E entusiasmo não é e nem deve ser uma virtude do juiz, ${ }^{12}$ enquanto agindo nessa qualidade. Obviamente porque, para gerar um novo consenso, é necessário um trabalho de mobilização e convencimento social.

Apesar de aparentemente Devlin assumir uma postura formalista ou de autocontenção do juiz, admite, ${ }^{13}$ todavia, a existência do ativismo judicial e até da atividade criativa do juiz, mas em casos raros, como o famoso caso Brown vs. Board of Education, ${ }^{14}$ em que a Suprema Corte dos Estados Unidos rechaçou definitivamente a doutrina dos "Separados mas Iguais", proibindo a segregação racial institucionalizada nas escolas americanas. A exceção, segundo o jurista, se explica pelo fato da Suprema Corte dos Estados Unidos ser composta não apenas por juízes de carreiras, mas por políticos e que faz parte do sistema americano a indicação de juízes baseado em suas posições políticas e ideologia. Nesse sentido, o ativismo, ou mesmo a criatividade, exercidos por aquele tribunal, são permitidos pelo próprio sistema. De qualquer forma, em geral, a postura de Devlin é no sentido de que o juiz deve agir sempre de acordo com o consenso plasmado na lei e, na dúvida, não deve agir:

\footnotetext{
Eu agora deixei claro que sou firmemente contra a criatividade judicial ou dinamismo como eu o defini, isto é, de operações judiciais antes do consenso. O limite do consenso não é uma linha claramente marcada, mas posso ter certeza do que seria não ter certeza ao dizer que um juiz que está em dúvida sobre o consenso não deve avançar de forma alguma. $\mathrm{O}$ consenso, por outro lado, já deixa em aberto um campo bastante amplo para a atividade judicial. ${ }^{15}$
}

Para além do problema da imparcialidade, Devlin apontava uma grande limitação, que inclusive inviabilizaria a atividade jurisdicional de criar direito novo. O Poder Judiciário não teria os subsídios necessários para a tomada de uma decisão adequada para os casos que não estivessem regulados, afirmando que o juiz, de modo geral, estaria restrito às informações

\footnotetext{
${ }^{10}$ Ibidem, p. 2.

${ }^{11}$ Ibidem, p. 2

12 Ibidem, p. 5.

${ }^{13}$ Ibidem, p. 6.

${ }^{14}$ Brown v. Board of Education, 357 U.S. 483.

${ }^{15}$ DEVLIN, Patrick Arthur. Judges and Lawmakers. In Modern Law Review, 39, 1976, p. 3.
} 
prestadas no processo pelas partes, afirmando que "existe um limite para o que o advogado pode fazer no tempo pago por seus clientes; litigantes estão interessados na decisão do seu caso e não no desenvolvimento da lei. As pessoas que possam estar interessadas não são representadas." 16

A forma de pensar de Devlin e daqueles que comungam de sua opinião é descrita analiticamente por Mauro Cappelletti:

\begin{abstract}
Os juízes, segundo esse entendimento, não têm possibilidade de desenvolver pessoalmente o tipo de investigações requeridas para uma obra criativa, que não podem se limitar às leis e aos precedentes, e envolvem problemas complexos e dados sociais, econômicos e políticos; não dispõem dos recursos, inclusive financeiros, mediante os quais os parlamentos, comissões legislativas e ministérios estão em condições de encarregar terceiros para efetuar pesquisas que, frequentemente, nem os legisladores e administradores saberiam desenvolver por si mesmos. ${ }^{17}$
\end{abstract}

De fato, ao Poder Judiciário cabe exclusivamente a tutela dos interesses individuais e coletivos e, por essa mesma razão, não tem a função de planejamento das políticas públicas, tal como previsto no art. 174 da Constituição da República. Em decorrência disso, do ponto de vista operacional, o Poder Judiciário não tem corpo técnico especializado das mais diversas áreas para tomar uma decisão. Ele está sempre adstrito ao processo, ao conflito trazido aos autos, de forma que, caso se proponha a implementar a política pública, provavelmente o fará de forma parcial, limitada aos interesses das partes, sem ter ciência do cenário global sobre o tema enfrentado, como saúde, educação, tributação, economia, dentre tantos outros.

Por outro lado, ao contrário de Devlin, Cappelletti admite que a atividade do juiz também é criadora do Direito. Para Cappelletti, e se referindo precipuamente ao sistema do Civil Law, a atividade jurisdicional está sujeita a limites substanciais e limites procedimentais. Contudo, aponta que, quanto aos limites substanciais, não são estes o fator fundamental de distinção entre Poder Judiciário e Poder Legislativo, posto que, tanto um quanto o outro estão sujeitos a limites substanciais no exercício de suas atividades típicas. A diferença é de grau, uma vez que o Poder Judiciário está sujeito a uma maior e mais detalhada lista de limitações, impostas pelas leis ordinárias (no sentido de infraconstitucionais) e aos precedentes judiciários

\footnotetext{
${ }^{16}$ Idem, p. 3.

${ }^{17}$ CAPPELLETTI, Mauro. Juízes legisladores? Porto Alegre: Sergio Antonio Fabris, 1993, p. 33.
} 
ordinários, ao passo em que o Poder Legislativo está sujeito a limites menos frequentes e menos precisos, ou seja, a Constituição escrita e as decisões da justiça constitucional. ${ }^{18}$

Entretanto, Cappelletti, mesmo admitindo o papel criador do juiz e muito embora aponte os meios técnicos que o Poder Judiciário dispõe para esse tipo de tomada de decisão, como o recurso ampliado a pareceres técnicos ou perícias, à intervenção de terceiros no processo, a figura do amicus curiae, ${ }^{19}$ o fato é que o jurista italiano não propõe uma solução adequada para superação da questão.

Com efeito, o Código de Processo Civil abre pelo menos três possibilidades, ainda que genéricas para que o juiz possa enfrentar essa situação. Por meio do princípio da cooperação $\left(\right.$ art. $\left.6^{\circ}\right)$ permite que o juiz conduza o processo e imponha às partes o ônus de juntar aos autos dados que revelem todo o contexto do conflito, como modelo de negócios das partes, realidade econômica do negócio, riscos do empreendimento, carga tributária incidente, dados sobre a concorrência no setor etc. Por sua vez, o $\S 3^{\circ}$ do art. 357 determina que, se a causa apresentar complexidade em matéria de fato ou de direito, deverá o juiz designar audiência para que o saneamento seja feito em cooperação com as partes, oportunidade em que o juiz, se for o caso, convocará as partes a integrar ou esclarecer suas alegações. Por fim, o $§ 1^{\circ}$ do art. 983 autoriza o Relator do incidente de resolução de demandas repetitiva - cuja decisão, por ser geral, gera impactos sistêmicos na ordem jurídica e na realidade como um todo - a designar audiência pública para ouvir o depoimento de pessoas com experiência e conhecimento na matéria que será julgada. O legislador ordinário, portanto, atento à existência de complexidade e à assimetria de informações, permite ao juiz buscar entender e compreender a realidade sobre a qual incidirá a decisão, permitindo, assim, uma melhor avaliação do caso, baseado em fatos e não meramente no formalismo.

Em trabalho dedicado exclusivamente sobre o tema, Cassio Scarpinella Bueno conclui que o instituto do amicus curiae é o instituto processual que permite que um terceiro imparcial e neutro ao processo forneça elementos para que o juiz melhor pondere aos fatos subjacentes

\footnotetext{
${ }^{18}$ Idem, p. 73-76.

${ }^{19}$ Idem, p. 89.
} 
às normas jurídicas e suas consequências práticas em todos os campos, de forma que possam interferir de forma consciente na própria interpretação e aplicação em cada caso. ${ }^{20}$

Por sua vez, os pressupostos do livre docente da PUC-SP são basicamente dois: a) a interpretação e aplicação do Direito pelo juiz revelam uma atividade criativa; ${ }^{21}$ b) a superação do dogma do positivismo formal, de que a atividade jurisdicional se limita a uma operação de mero raciocínio lógico-silogístico, em que a premissa maior é a lei e a premissa menor, o fato. Por outro lado, o pensamento revela a importância do fato e de todas as suas peculiaridades, para que o juiz interprete e aplique a lei de forma consciente, levando a complexidade fática e os seus matizes na tomada de decisão. Nesse particular, transcreve-se trecho da obra citada:

O que queremos destacar com a afirmação do parágrafo anterior [a crença de que o juiz sempre sabe tudo é um dogma] é que, se o "direito" e o "fato", mais do que nunca, precisam andar juntos para a própria interpretação e aplicação do direito, já não há mais condições efetivas de esperar do juiz que ele simplesmente saiba tudo sobre tudo e na sua profundidade que, muitas vezes, é-lhes impossível vir a saber.

A essa mesma conclusão, parece haver chegado Renato Becho, que já inicia seu trabalho problematizando o dogma da subsunção, asseverando que o raciocínio puramente lógico já não pode ser utilizado, de forma exclusiva, como parâmetro de compreensão das decisões administrativa e judicial, particularmente as tributárias: "A clássica subsunção do fato à norma não tem sido mais suficiente para demonstrar como as decisões vêm sendo tomadas, o que aponta para a participação de outros elementos, que podem ser interpretativos, não evidenciados na decisão ou mesmo não jurídicos.” 22

A problemática está em identificar a partir de que momento o caso concreto, em toda sua complexidade, pode permitir a criação de uma norma jurídica particular ao caso concreto, sem que haja violação ao princípio da separação dos poderes, levando em conta, ainda, que o Poder Judiciário não tem funções nem estrutura para o planejamento de políticas públicas.

Importante ainda ressaltar, neste ponto, que a atividade jurisdicional, principalmente nos sistemas de Civil Law, em que o direito retira seu fundamento de validade da lei, emanada pelo Poder Legislativo, produzirá um ato válido desde que respeite o Direito Positivo, não sendo

\footnotetext{
${ }^{20}$ BUENO, Cassio Scarpinella. Amicus Curiae no Processo Civil Brasileiro: um terceiro enigmático. $3^{\mathrm{a}}$ edição. São Paulo: Saraiva, 2012, p. 69.

${ }^{21}$ Idem, p. 65.

22 BECHO, Renato Lopes. Considerações sobre dados extrajurídicos que podem estar influenciando os julgamentos tributários. Revista Brasileira a Advocacia, São Paulo, ano 3, n. 8, p. 156, jan./mar. 2018.
} 
possível criar uma norma construída parte com elementos legais e parte com elementos estranhos ao próprio Direito. A esse respeito, a doutrina de Geraldo Ataliba, no sentido de que o Direito tem uma estrutura própria, de modo que os elementos não jurídicos, isto é, aqueles que não foram introduzidos no ordenamento, não podem derrogá-lo:

Os institutos e categorias jurídicas só são válidos e operantes nos quadrantes do direito. Daí o terrível engano dos que pensam que a economia e o direito podem estudar um mesmo objeto, o tributo por exemplo, intercambiando informações, observações, princípios e técnicas de compreensão, operação e aplicação. O conceito de tributo, para o direito, nasce e esgota-se no universo jurídico. ${ }^{23}$

Ainda nos utilizando dos ensinamentos de Ataliba, o jurista destaca o caráter da atributividade da norma jurídica, o qual permite a esta "atribuir qualidades e efeitos às coisas e comportamentos, que lhe dá a virtude de imputar efeitos próprios seus (jurídicos) às coisas que recaem sob seu poder." 24

Portanto, a norma jurídica, inclusive a individual e concreta, como a sentença judicial, atribui qualidades e efeitos a determinados fatos, com a consequente imputação de efeitos jurídicos próprios, de forma coativa. Nesse sentido, atribuir normatividade a um fato significa questionar até que ponto esse fato pode ser inserido em dada categoria jurídica para que faça surgir, em uma dada relação jurídica, um direito de uma parte e a obrigação correspondente de outra.

Especificando ainda a hipótese, questiona-se até que ponto os efeitos causados pela pandemia do vírus COVID-19 podem ser enquadrados em uma categoria jurídica, tornando-os aptos a que o juiz impute ao Estado-fisco a obrigação de se abster de recolher tributo por determinado período de tempo.

Para tanto, necessário demonstrar, primeiramente, a complexidade fática que exsurge da pandemia para, a partir de então, contrastar com as balizas jurídicas aplicáveis ao tema.

\footnotetext{
${ }^{23}$ ATALIBA, Geraldo. Hipótese de Incidência Tributária. 6ª edição. São Paulo: Malheiros, 2006, p. 24.

${ }^{24}$ Idem, p. 28.
} 


\section{COMPLEXIDADES INTERNAS E EXTERNAS}

Nesse ponto, é relevante a definição de complexidade fornecida por Richard Posner. Por complexidade, Posner $^{25}$ não se dirige ao nível de dificuldade de qualquer questão a ser enfrentada, mas, sim, à complexidade do caso que envolve sistemas, grosso modo dizendo, um conflito que envolva interconexões complicadas ou interações entre os elementos que compõem o sistema. Para Posner, existem as complexidades internas e externas, dependendo de elas estarem dentro ou fora da lei. Exemplos de complexidade interna estão ligados ao sistema legal, como textos normativos (lei estatutária estadual, common law estadual, lei constitucional estadual, lei estatutária federal, common law federal, lei constitucional federal e precedentes), ou questões que dizem respeito à interpretação. As complexidades externas, por outro lado, fazem parte de um universo virtualmente infinito e fora do Direito, a exemplo, prova de DNA, economia, sistemas de vigilância eletrônica, energia, estimativa de danos econômicos, provas médicas e epidemiologia. ${ }^{26}$

Posner atribui em grande parte à complexidade, principalmente a externa, a atitude formalista do juiz. Segundo ele, para evitar se aprofundar nas complexidades, o juiz adapta a linguagem semântica aos fatos, e não estes àqueles, e produz uma decisão sem se ater às peculiaridades de cada caso. De fato, ao assim proceder, o juiz recorta a realidade e a transporta para a linguagem das estruturas da ciência jurídica, definindo um limite inexistente entre o que é o Direito e o que é a realidade.

Assim, as complexidades externas estão relativamente fora do alcance do juiz e as regras tradicionais do processo civil, de maneira geral, não fornecem instrumentos para que essa lacuna seja preenchida. Mas, segundo Posner, se tais espaços não forem preenchidos por conhecimento empírico dos fatos, será escondido por meio da tomada de decisão meramente formal. $^{27}$

\footnotetext{
${ }^{25}$ POSNER, Richard Allen. Reflections on judging. Cambridge: Harvard University Press, 2013. p. 108-120, p. 34.

26 Idem, p. 15.

${ }^{27}$ POSNER, Richard Allen. Law, pragmatism and democracy. Cambridge: Harvard University Press, 2003. p. 76.
} 
Diferentemente de Devlin, Posner entende que o juiz exerce uma atividade criativa, assim como Cappelletti, conforme registrado. Segundo o jurista americano, existem dois aspectos albergados pelo princípio da separação de poderes: a primeira que diz respeito à independência da função jurisdicional da função legislativa e, por consequência, a independência do juiz em relação ao legislador. $\mathrm{O}$ outro aspecto diz respeito ao juiz, se mero aplicador do Direito ou se ele de fato cria a lei. Posner afirma que o juiz cria Direito, não apenas quando está julgando o caso com base na Common Law, ou nos precedentes, sendo estes o próprio fundamento de validade do Direito, mas também quando julga os casos baseado no Direito Constitucional e no Direito Estatutário, ${ }^{28}$ a lei em sentido formal e material.

É exatamente baseado no enfrentamento de casos complexos que Posner distingue a atitude do juiz formalista e do juiz realista. Conforme Posner, ${ }^{29}$ o juiz formalista tem as seguintes características: é adepto da subsunção, está acostumado a considerar a lei como um dado estático e a tarefa do advogado é adequar a realidade à lei. Com base nos fatos e argumentos apresentados pelas partes, o juiz combina-os com os precedentes, textos constitucionais e legislativos, seguindo uma metodologia puramente semântica. Além disso, apenas os materiais ortodoxos de análise jurídica - estatutos, constituições, regulamentos, precedentes, outros documentos legais - são lei; todo o resto é política ou economia.

$\mathrm{Na}$ abordagem formalista, o intérprete é indiferente às consequências de suas interpretações no mundo real; não é responsável por essas consequências. Se são inconvenientes, é exatamente porque a lei é um dado estático e deve ser modificada pelo Poder Legislativo. Por fim, para tal corrente, os juízes que levam em consideração as consequências de interpretações alternativas estão saindo da lei, logo agindo como políticos.

Por outro lado, e no extremo oposto, está o juiz realista. Este é cético em relação ao formalismo, considerando-o mais retórico que analítico - uma retórica que esconde as verdadeiras fontes de decisão. Ademais, coloca ênfase nas consequências das decisões judiciais, sistêmicas e específicas do caso e evita a chamada justiça míope, isto é, aquela que responde apenas às ações das partes no caso particular.

\footnotetext{
28 Idem, p. 61.

${ }^{29}$ POSNER, Richard Allen. Reflections on judging. Cambridge: Harvard University Press, 2013, p. 108-120.
} 
A justiça, segundo essa abordagem, é, portanto, analítica e empírica, em vez de meramente intuitiva e política. Por fim, leva em conta as consequências sistemáticas, incluindo o efeito de uma doutrina ou decisão sobre a previsibilidade da lei, sobre o volume de processos, sobre a administração, sobre o trabalho de outros ramos do governo (como o legislativo, que seria desorganizado se os juízes não prestassem atenção à linguagem estatutária) e às expectativas razoáveis tanto privadas quanto públicas.

O papel do juiz é, segundo Posner, julgar os casos com base em argumentos cientificamente comprovados, sendo esta uma proposta de legitimação mais adequada do que a busca por consensos objetivos sobre o que é o Direito. Analisar as consequências de uma decisão, entretanto, exige um estudo empírico e o juiz deve seguir o mesmo método de investigação de uma pesquisa científica para poder chegar às suas conclusões. Nas palavras de Posner, o propósito da análise econômica do Direito é buscar uma teoria geral que forneça elementos objetivos para a formação da decisão judicial:

O esforço mais ambicioso e provavelmente o mais influente dos últimos anos para
elaborar um conceito abrangente de justiça que explique a tomada de decisão judicial
e a coloque de maneira objetiva é o de estudiosos que trabalham no campo
interdisciplinar de "direito e economia", como análise econômica do direito é
geralmente chamada. ${ }^{30}$

Pode-se concluir assim que Devlin limita a atividade do juiz ao consenso das escolhas legislativas, restringindo, assim, a discricionariedade judicial. Por outro lado, para Posner, o juiz deve buscar no consenso científico dados concretos para sua tomada de decisão, o que acaba por ampliar a discricionariedade judicial. Assim, Devlin ressalta o limite político da decisão judicial. Posner, por outro lado, reforça os limites fáticos do conhecimento humano.

\footnotetext{
30 "The most ambitious and probably the most influential effort in recent years to elaborate an overarching concept of justice that will both explain judicial decision making and place it on an objective basis is that of scholars working in the interdisciplinary field of "law and economics," as economic analysis of law is usually called." (POSNER, Richard Allen. The problems of jurisprudence. Cambridge: Harvard University Press, 1993. p. 247).
} 


\section{COVID-19 E SUA COMPLEXIDADE: AS INCERTEZAS CIENTÍFICAS SOBRE O TEMA}

Neste item, pretende-se levantar alguns dados publicados em artigos científicos acerca do vírus COVID-19 e principalmente sobre as medidas sociais preventivas que têm por objetivo a redução da taxa de transmissão da doença. $O$ intuito é demonstrar que o tema é complexo e incerto do ponto de vista científico e que, por isso, exige uma tomada de decisão do Legislativo e do Executivo de maneira sistemática, e não meramente pontual, tal qual seria tomada pelo Poder Judiciário.

O vírus Covid-19 faz parte de uma tríade da família do Coronavírus, formado por SARS-2003, MERS-2012 e COVID-2019. O chamado SARS é a sigla em inglês de severe acute respiratory syndrome coronavirus 2, e o número aposto 2003 designa o ano em que se constatou que aquele vírus se tornou epidêmico. Por sua vez, MERS é a sigla em inglês para Middle East respiratory syndrome, descoberta no ano de 2012. Por fim, COVID é a sigla em inglês para coronavirus desease, constatado em dezembro de 2019 pela primeira vez em Wuhan, na China. ${ }^{31}$

Segundo dados científicos, apesar de pertencerem à mesma família, cada um dos vírus tem formas de atuação próprias, principalmente o COVID-19, que vem se mostrando aquele que mais rapidamente se alastra em relação aos SARS. ${ }^{32}$ Ademais, os estudos relatam que a China admitiu a eventual e futura ocorrência de outras epidemias, tendo enfatizado a importância de se aprimorar o sistema de saúde após o surgimento das duas primeiras espécies do coronavírus. ${ }^{33} \mathrm{O}$ vírus também pode ser classificado como uma zoonose, já que os estudos demonstram que $98 \%$ de seu genoma é idêntico ao coronavírus do morcego, reforçando, assim, a tese de que sua origem é de um mercado de frutos do mar e animais vivos de Wuhan.

O COVID-19 se espalha por via oral ou por gotículas nasais e, principalmente, o vírus pode se difundir pelo ar, causando infecção em pessoas saudáveis. O período de incubação, isto

\footnotetext{
31 Eloi Marijon, Nicole Karam, Daniel Jost, David Perrot, Benoit Frattini, Clément Derkenne, Ardalan Sharifzadehgan, Victor Waldmann, Frankie Beganton,Kumar Narayanan, Antoine Lafont, Wulfran Bougouin, Xavier. JouvenOut-of-hospital cardiac arrest during the COVID-19 pandemic in Paris, France: a population-based, observational study. Disponível em https://www.thelancet.com/pdfs/journals/lanpub/PIIS2468-2667(20)301171.pdf. Acessado em 28/05/2020.

${ }^{32}$ Idem.

${ }^{33}$ Idem.
} 
é, o tempo entre a infecção causada pelo vírus até o aparecimento de sintomas, varia de dois a catorze dias, com média de cinco a seis dias. Há, contudo, estudos que apontam que o período de incubação seria de até vinte e quatro dias. ${ }^{34}$

A complexidade em relação ao conhecimento do vírus refere-se particularmente à taxa de transmissão. Há uma variação consideração quanto ao número de pessoas que podem ser infectadas, em média, por aquele portador da doença e, diferentes estudos apontam taxa média entre 2,2 até 6,47. Há ainda estudos que indicam que taxa de transmissão diminui na medida em que as medidas preventivas são mais efetivas. ${ }^{35}$ Tais estudos, reforçam, portanto, que, além dos fatores inerentes à doença, a eficácia do sistema de saúde e a capacidade de se tomarem medidas coletivas de prevenção podem diminuir a taxa de transmissão e, portanto, o índice de incidência da doença.

No dia 31 de dezembro de 2019, a Organização Mundial de Saúde (OMS) foi informada pelo Governo chinês da constatação de um surto de pneumonia de causas desconhecidas reportada, ocorrida na cidade de Wuhan. No dia 5 de janeiro de 2020, a OMS tornou público o relato da epidemia. No dia 11 de fevereiro, foi alterada a nomenclatura da doença para COVID19 sob o fundamento de que, ao contrário da MERS, a doença já não poderia ser utilizada para designar tão somente uma região afetada, já que já havia se iniciado seu alastramento para outras partes do mundo, não mais contíguas à sua origem. Um mês depois, no dia 11 de março, a OMS caracteriza a COVID-19 como uma pandemia. ${ }^{36}$

Ainda segundo dados da OMS, no dia 11 de março o mundo tinha o total acumulado de 124.101 casos. No dia 30 de maio de 2020, data do fechamento deste trabalho, foram registrados 5.819.962 de casos e 362.786 mortes em todo o mundo. No Brasil, levando em consideração as mesmas datas, o número de casos subiu de 34 para 465.166 , com o total de 27.878 mortes. ${ }^{37}$

Diante da falta de informações completas e sistêmicas sobre a doença, as medidas preventivas têm sido a forma encontrada pela Organização Mundial de Saúde para controlar a curva do gráfico, mitigando, assim a transmissão e a ocorrência de mais óbitos. As medidas

\footnotetext{
${ }^{34}$ Idem.

35 Idem.

36 Disponível em https://www.who.int/emergencies/diseases/novel-coronavirus-2019/events-as-they-happen. Acessado em 29/05/2020.

${ }^{37}$ Disponível em https://covid19.who.int/. Acessado em 29/05/2020.
} 
preventivas são as medidas de reforço dos hábitos de higiene, as relacionadas a etiqueta social e, principalmente, as medidas sociais de distanciamento físico entre as pessoas, que variam de país a país. A recomendação oficial é que os governos promovam a disponibilização de testes e, nos casos confirmados, o portador deve ser isolado do convívio social e seus parentes e pessoas próximas devem ser submetidas a quarentena. ${ }^{38}$

A Organização Mundial de Saúde, levando em conta as medidas tomadas pelos diversos países para enfrentar a pandemia, pondera que a tomada de medidas de saúde pública em larga escala, como restrições de locomoção, fechamento de escolas e atividades empresariais, quarentena geográfica, restrições a viagens internacionais e eventual fechamento total da economia, o chamado lockdown ou shutdown, devem ser tomados levando critérios complexos como fatores epidemiológicos como a taxa de incidência da doença e de internações hospitalares, a capacidade do sistema público e privado de saúde de promover o atendimento e tratamento dos infectados, e a existência de intervenções farmacêuticas, destacando-se que não há, ainda, uma vacina para combater o vírus. De se registrar, ainda, que na mesma recomendação foi apontado que devem ser levadas em consideração as consequências sociais e os custos econômicos de tais medidas, que podem ser consideráveis a depender da incidência da doença em determinado país. ${ }^{39}$

Ainda acerca das incertezas e assimetrias que giram em torno do tema, é relevante destacar alguns dados que demonstram os diferentes riscos ocupacionais do COVID-19. O jornal The New York Times publicou pesquisa feita no $\mathrm{O}^{*} \mathrm{NET},{ }^{40} \mathrm{um}$ banco de dados mantido pelo Departamento de Trabalho dos Estados Unidos, que descreve inúmeros aspectos físicos dos diferentes tipos de trabalho. Segundo a pesquisa, a doença causada pelo COVID-19 impacta radicalmente as categorias de trabalhadores.

Dentre as profissões mais afetadas estão os dentistas, médicos e demais profissionais da saúde, enquanto policiais e caixas de supermercado estão em um quadrante situado entre os moderadamente afetados e os mais afetados. Em uma posição intermediária, então profissionais como prestadores de serviço em lavanderias, empregados domésticos, transportadores e

\footnotetext{
38 Disponível em https://apps.who.int/iris/bitstream/handle/10665/331773/WHO-2019-nCoVAdjusting_PH_measures-2020.1-eng.pdf. Acessado em 01/06/2020.

${ }^{39}$ Idem. Acessado em 01/06/2020.

40 Disponível em https://www.nytimes.com/interactive/2020/03/15/business/economy/coronavirus-workerrisk.html. Acessado em 01/06/2020.
} 
professores. Por fim em uma fase de risco baixo ou baixíssimo de sujeição ao vírus, estão carpinteiros, advogados, cientistas políticos, analistas financeiros, entre outros.

O que se pretende trazer com essas informações é que a pandemia afeta a todos de maneira horizontal, já que todos estão sujeitos às medidas de isolamento. Contudo, a depender da profissão, há profissionais que são inteiramente impactados e sujeitos não só ao vírus, mas aos efeitos das medidas de distanciamento, de modo que o COVID-19 afeta diferentemente várias pessoas e, por consequência, as diversas atividades econômicas de maneiras verticalmente desiguais. Em outras palavras, e trazendo para o plano do Direito Tributário, diferentes contribuintes serão impactados de maneira diversa, a depender do ramo de atividade a que se dedicam.

Essa diversidade deve ser, portanto, levada em consideração na tomada de decisões públicas para o enfrentamento da situação emergencial que a todos assola. Nos termos das recomendações da Organização Mundial da Saúde, conforme já apontado, essas particularidades devem ser levadas em consideração pelos países na formulação da política a ser adotada.

No Brasil, a Lei $\mathrm{n}^{\mathrm{o}} 13.979$, de 06/02/2020, que dispõe sobre as medidas para enfrentamento da emergência de saúde pública de importância internacional decorrente do COVID-19, estabeleceu, no art. $3^{\circ}$, medidas sociais que poderão ser tomadas para o enfrentamento da pandemia, dentre elas, o isolamento social, a quarentena, realização compulsória de testes, dentre outros.

Por sua vez, o Congresso Nacional decretou estado de calamidade pública exclusivamente para os efeitos do art. 65 da Lei Complementar $n^{\circ} 101$ de 04/05/2001 - a Lei de Responsabilidade Fiscal - particularmente para que não seja necessário obedecer aos limites de endividamento dos entes federativos, permitindo, assim, a alocação de receitas públicas para fazer face às despesas extraordinárias no combate à pandemia.

No Estado de São Paulo, no dia 22/03/2020, foi decretada a quarentena em todo o território estadual, determinando a suspensão das atividades empresariais, ressalvados os serviços categorizados como essenciais, conforme Decreto $n^{\circ} 64.881 / 2020$. Por sua vez, o Decreto $n^{\circ} 64.994$, de 28/05/2020, prorrogou a quarentena até o dia 15/06/2020. 
É nesse cenário de incidência da pandemia, de um lado, e da tomada de medidas de distanciamento social, de outro, que a complexidade do COVID-19 afeta a atividade econômica, interferindo não somente na redução imediata da demanda, quanto na da oferta, o que gerou, entre outros efeitos, como a supressão aproximadamente 1.777 .000 de emprego no primeiro trimestre de 2020 em relação ao último semestre de 2019, segundo a PNAD, realizada pelo IBGE. ${ }^{41}$ Ao mesmo tempo, conforme relatório da Receita Federal do Brasil, no primeiro trimestre de 2020, houve a redução de 28,79\% da arrecadação federal em relação ao mesmo período do ano passado, tendo caído em $\mathrm{R} \$ 37.738 .000 .000$ (trinta e sete bilhões e setecentos e trinta e oito milhões de reais). Além disso, e seguindo essas perdas, o Brasil empobreceu 1,5\% no primeiro trimestre do ano de 2020 em relação ao último trimestre do ano passado, conforme dados do IBGE divulgados em 29/05/2020. ${ }^{42}$

Com a referida queda da demanda e da oferta, diversos contribuintes, normalmente sociedades empresárias, buscam no Poder Judiciário uma norma jurídica individual e concreta com o objetivo de diferir o pagamento dos tributos vencidos e vincendos até, pelo menos, o final do mês de junho de 2020. O fundamento é o impacto da pandemia e do isolamento social na atividade empresarial, e na necessidade premente de uma regra que permita a realocação de recursos escassos em outros custos operacionais, seja para garantir a solvência, seja para, em outros casos, garantir a própria continuidade da atividade empresarial.

É, portanto, nesse contexto, que o juiz se vê entre ponderações econômicas e sociais absolutamente justas e a ausência de um regramento jurídico adequado para o tratamento da situação. Esse quadro torna aguda a tensão recorrente entre o Direito positivo e o fato social. Uma visão pragmática do Direito, contudo, não pode simplesmente rejeitar de plano as complexidades que surgem com os fatos relacionados à COVID-19; no entanto, não deve esgarçar as restrições impostas pelo Estado de Direito e pelas próprias limitações técnicas e políticas inerentes ao Poder Judiciário.

\footnotetext{
${ }^{41}$ Disponível em ftp://ftp.ibge.gov.br/Trabalho_e_Rendimento/Pesquisa_Nacional_por_Amostra_de_Domicilios_continua/Trimes tral/Tabelas/2020/2020_1_trimestre/pnadc_202001_tabelas_brasil.zip. Acessado em 28/05/2020.

${ }^{42}$ Disponível em https://www.ibge.gov.br/estatisticas/economicas/contas-nacionais/9300-contas-nacionaistrimestrais.html?=\&t=destaques\&utm_source=landing\&utm_medium=explica\&utm_campaign=pib\#evolucaotaxa. Acessado em 31/05/2020.
} 


\section{AÇÃO JUDICIAL PARA SUSPENSÃO DO CUMPRIMENTO DE OBRIGAÇÕES TRIBUTÁRIAS E PROCESSO TRIBUTÁRIO}

A caracterização de uma demanda como tipicamente tributária (ou penal, civil etc) depende da relação jurídica de direito material por ela veiculada. Paulo Cesar Conrado elenca os elementos de toda relação material: sujeito ativo, sujeito passivo, objeto e direito subjetivo. Ele assevera que, para que a demanda seja de Direito Tributário, é necessário que todos esses elementos estejam alinhados com o ordenamento jurídico tributário. Para tanto, o sujeito ativo será o Estado-fisco ou pessoa que haja em seu nome; o sujeito passivo será o contribuinte ou pessoa a ele equiparada; o objeto é o tributo, assim entendida a prestação pecuniária compulsória instituída em lei que não constitua sanção por ato ilícito; o direito subjetivo sendo titularizado pelo Estado tendo por objeto a prestação pecuniária correspondente e; o dever jurídico do contribuinte de pagar o tributo. ${ }^{43}$

Uma ação classifica-se pelos seus elementos: partes, causa de pedir e pedido. O conjunto de regras a ser aplicado à relação material depende, portanto, da relação material a qual a ação se reporta, podendo-se assim vislumbrar uma demanda penal, civil, tributária etc. Sendo assim, e utilizando os ensinamentos acima expostos, a demanda tributária terá por partes o Fisco e o contribuinte; como causa de pedir próxima o conjunto de regras do direito positivo que regulam aquela relação; como causa de pedir remota um fato jurídico tributário, como a violação, por parte do Estado, de alguma regra concernente às limitações constitucionais ao poder de tributar ou aos aspectos material, temporal, pessoal, espacial ou quantitativo da hipótese de incidência. E, por fim, o pedido que, se for por parte do contribuinte, especificamente, pode ser condenatório, constitutivo, mandamental ou declaratório.

Com o advento da pandemia causada pelo vírus COVID-19, alguns contribuintes estão ajuizando ações judiciais, nomeadamente mandados de segurança, para que lhes seja reconhecido o direito líquido e certo ao diferimento do vencimento de tributos federais devidos para até o dia último dia útil do $3^{\circ}$ (terceiro) mês subsequente do Decreto do Estado de São

\footnotetext{
${ }^{43}$ CONRADO, Paulo Cesar. Processo Tributário. 2a edição. São Paulo: Quartier Latin, 2007, p. 27-28.
} 
Paulo no 64.879 de 20 de março de 2020 - que reconhece o estado de calamidade pública, decorrente da pandemia do COVID-19, que atinge o Brasil.

Requer-se ainda, pedidos decorrentes do diferimento dos tributos: a suspensão da exigibilidade do crédito tributário durante o período de diferimento dos vencimentos, a abstenção por parte da Receita Federal do Brasil de aplicar qualquer penalidade pelo eventual recolhimento a destempo do tributo, ou mesmo de exercer qualquer restrição ao direito pleiteado, como inscrição do nome do contribuinte em qualquer cadastro de inadimplentes, ou indeferir emissão de Certidão Positiva com Efeitos de Negativa.

Alega-se, para tanto, em termos gerais, que as medidas de isolamento social determinadas pelo Estado, e a consequente redução da circulação de pessoas, impactaram a situação financeira do contribuinte, a ponto de comprometer o fluxo de caixa e dos pagamentos de funcionários, fornecedores e mesmo dos tributos. Com base nesse fato, aduzem, ainda, que o ordenamento jurídico teria dispensado um tratamento específico para situações de calamidade pública, requerendo-se, nessa medida, a aplicação da Portaria do Ministério da Fazenda no 12 , de 20 de janeiro de 2012.

$\mathrm{O}$ artigo $1^{\circ}$ da Portaria $\mathrm{n}^{\circ} 12$, de 20 de janeiro de 2012 dispõe o seguinte:

Art. $1^{\circ}$ As datas de vencimento de tributos federais administrados pela Secretaria da Receita Federal do Brasil (RFB), devidos pelos sujeitos passivos domiciliados nos municípios abrangidos por decreto estadual que tenha reconhecido estado de calamidade pública, ficam prorrogadas para o último dia útil do $3^{\circ}$ (terceiro) mês subsequente.

$\S 1^{\circ} \mathrm{O}$ disposto no caput aplica-se ao mês da ocorrência do evento que ensejou a decretação do estado de calamidade pública e ao mês subsequente.

$\S 2^{\circ}$ A prorrogação do prazo a que se refere o caput não implica direito à restituição de quantias eventualmente já recolhidas.

$\S 3^{\circ} \mathrm{O}$ disposto neste artigo aplica-se também às datas de vencimento das parcelas de débitos objeto de parcelamento concedido pela Procuradoria-Geral da Fazenda Nacional (PGFN) e pela RFB.

Nesse cenário, fazendo-se o cotejo com os elementos da ação, conclui-se que as partes são contribuinte, de um lado, e fisco, do outro. A causa de pedir remota é um fato complexo: os efeitos financeiros causados pelas medidas de isolamento impostas pelos governos estaduais como preventivas ao alastramento da pandemia causada pelo vírus COVID-19. A causa de pedir próxima é o suposto tratamento dispensado aos casos de calamidade pública, previsto na portaria da Receita Federal do Brasil. Por fim, o pedido é o diferimento dos tributos, conforme 
as datas definidas na portaria e, por via de consequência, a abstenção, por parte do Fisco, de aplicar multas e outras medidas restritivas de crédito em relação ao objeto do pedido.

Questiona-se, ante esse cenário, se as demandas assim genericamente referidas são tipicamente tributárias.

O pedido tem por objetivo a suspensão de obrigação tributária, por decisão judicial, em casos de pandemia. Trata-se de pedido que modifica a relação jurídica tributária em seu momento consequente, qual seja, o prazo para pagamento do tributo e, durante o período, caso seja assim julgado procedente, o crédito tributário estará suspenso, nos termos do artigo 151, IV ou V, do CTN, a depender do tipo de procedimento manejado - mandado de segurança ou procedimento comum. Assim, sob o ponto de vista do pedido, a demanda é tipicamente tributária.

Nesse ponto, poder-se-ia questionar se o pedido do contribuinte não seria uma moratória, outra modalidade de suspensão do crédito tributário, prevista no artigo 151, I, do CTN.

\begin{abstract}
A moratória consiste na concessão legal de um período de tolerância na exigência de dívidas, não a determinado contribuinte, mas a toda uma categoria deles, conforme a atividade profissional, a região ou outro critério. Pode ser também geral, abrangendo todas e quaisquer dívidas, em caso de crise política ou econômica de extrema gravidade.

(...)

É medida de ordem pública em caso de calamidade pública, como seca, enchente, terremoto etc., numa cidade ou região, ou de comoção política, que perturba violentamente a economia, causando pânico financeiro ou impossibilidade material de satisfação das dívidas. A moratória representa mal menor, evitando que se alastre catastroficamente a crise ainda limitada a certas categorias profissionais ou a certas regiões.

(...)

A moratória, seja de caráter geral, seja de caráter individual, há de ter base em lei. ${ }^{44}$ (grifos nossos)
\end{abstract}

A moratória tem duas características que formam sua estrutura jurídica que, em conjunto, a distinguem de qualquer outra causa suspensiva: trata-se de prorrogação de prazo para pagamento ou de outorga de novo prazo, se já esgotado o prazo originariamente ${ }^{45}$ e deve ser concedida, necessariamente, por meio de lei, nos termos do artigo 152, do CTN. Ou seja, é um benefício criado pela pessoa política competente para a instituição do respectivo tributo,

\footnotetext{
${ }^{44}$ BALEEIRO, Aliomar. Direito Tributário Brasileiro. $11^{\text {a }}$ edição. Rio de Janeiro: Forense, 2007, p. 844-845.

${ }^{45}$ COSTA, Regina Helena. Curso de Direito Tributário. $8^{a}$ edição. São Paulo: Saraiva, 2018, p. 266.
} 
por meio do Poder Legislativo. Nesse sentido, ilegal seria pleitear a concessão de moratória junto ao Poder Judiciário.

Por fim, em continuidade à análise acerca dos elementos da ação judicial em questão, sob o ponto de vista da causa de pedir, trata-se de demanda que tem origem em um fato complexo e estranho à relação jurídica tributária, isto é, não decorre diretamente de um ato do Fisco que, por exemplo, extrapolou os limites da hipótese de incidência de um determinado tributo ou violou alguma limitação constitucional ao poder de tributar. Entretanto, esse fato é introduzido no Direito a partir de uma regra que estabelece uma relação de causalidade jurídica entre aquele fato - a calamidade pública - e uma causa de suspensão de obrigação tributária. Portanto, nesse sentido, a causa de pedir próxima é uma norma jurídica tributária.

Do exposto, conclui-se que a demanda tem como objetivo a suspensão do pagamento dos tributos federais em decorrência dos efeitos financeiros causados pelo vírus COVID-19 é tipicamente tributária, devendo ser aplicado, ao caso, as normas materiais e processuais tributárias.

\section{APLICAÇÃO DA PORTARIA $\mathbf{N}^{\circ}$ 12, DE 20 DE JANEIRO DE 2012 SOB O FUNDAMENTO DOS EFEITOS FINANCEIROS CAUSADOS PELO COVID-19}

Tendo se admitido o manejo de ações judiciais com o escopo de suspender o cumprimento de obrigações tributárias, resta saber se a regra prevista na Portaria $\mathrm{n}^{\mathrm{o}} 12$ do Ministério da Fazenda, de 10/01/2012, poderia ser aplicada aos efeitos financeiros causados pelo COVID-19.

Como já pontuado, os contribuintes alegam que o ordenamento jurídico teria dado tratamento para os casos de calamidade. $\mathrm{O}$ artigo $1^{\circ}$ da referida portaria prorroga as datas de vencimento de todos os tributos federais administrados pela Receita Federal do Brasil, de forma indistinta, aos sujeitos passivos domiciliados nos municípios abrangidos por decreto estadual que tenha reconhecido estado de calamidade pública. Sem mesmo se ater à exposição de motivos do ato normativo, é nítida que sua finalidade é a de proteger pessoas indeterminadas, 
mas dentro de uma área de abrangência delimitada por um decreto estadual, o que englobaria, um ou alguns municípios atingidos por uma certa calamidade, fatos infelizmente cada vez mais corriqueiros no país, como o ocorrido nas cidades de Mariana e Brumadinho, em Minas Gerais.

A redação, nitidamente, traz uma hipótese de calamidade, mas qualificada por sua demarcação geográfica, o que faz, por si só, com que o ato normativo não tenha incidência em caso de uma calamidade gerada por uma pandemia, isto é, uma epidemia que não está mais confinada ao local em que se originou, como é o caso daquela causada pelo Covid-19.

Mas, ainda, que se pretenda superar essa diferença semântica e operacional entre um e outro tipo de calamidade, poder-se-ia apelar para uma integração do direito por meio de analogia, método admitido em direito tributário, desde que não resulte em cobrança de imposto não devido, nos termos do artigo 108 , I e $\S 1^{\circ}$, do CTN. Entretanto, a finalidade da norma que protege populações acometidas por calamidade pública local é de resguardar situações de extrema penúria, que comprometem a própria sobrevivência física das pessoas afetadas, o que justificaria a alocação dos valores a serem recolhidos a título de tributo para despesas com comida, moradia, roupas e ainda funeral de familiares, por exemplo.

Essa realidade é completamente distinta do estado de calamidade pública provocado pelo vírus COVID-19, seja do ponto de vista fático, seja do ponto de vista jurídico.

De fato, conforme espera-se ter sido demonstrado, os efeitos da pandemia e das medidas sociais de isolamento afetam horizontalmente a todos, mas em graus distintos, motivo pelo qual aplicar analogicamente uma portaria de forma indistinta a todas a sociedades empresárias que se arvoram nos direitos conferidos pela norma contraria o próprio fundamento da analogia: aplicar a mesma norma a pessoas que materialmente encontram-se na mesma situação fática e jurídica.

Por esse motivo, conclui-se que a complexidade da situação não autoriza a aplicação de analogia. 


\section{LEGALIDADE TRIBUTÁRIA E LIMITES À INTERPRETAÇÃO JUDICIAL}

Não é possível retirar do ordenamento jurídico direito subjetivo garantido ao contribuinte para diferir o recolhimento do tributo sem que haja lei expressa nesse sentido. Embora a norma tributária seja absolutamente igual, em sua estrutura, às demais normas jurídicas, ${ }^{46}$ o Direito Tributário é o ramo do Direito que mais mereceu regulação pela Constituição Federal, tendo esta sido extremamente analítica ao emitir as regras que delineiam a relação jurídico-tributária, estabelecida entre o Estado e o contribuinte. Nessa ordem de ideias, é ínsito ao Direito Tributário o princípio da legalidade estrita, previsto no art. 150, I do texto constitucional e especificado pelo CTN, lei complementar, conforme art. 146, II da CF/88.

Dando concreção às limitações constitucionais do poder de tributar, o do art. 97 do CTN determina que somente a lei pode estabelecer as hipóteses de exclusão, suspensão e extinção de créditos tributários. Transcreve-se a seguir o comando legal:

\footnotetext{
Art. 97. Somente a lei pode estabelecer:

(...)

VI - as hipóteses de exclusão, suspensão e extinção de créditos tributários, ou de dispensa ou redução de penalidades.
}

Assim, nos termos do tratamento constitucional e complementar, é necessário que exista uma lei expressa que determine uma causa de suspensão do crédito tributário. Nesse sentido, viola a Constituição e a lei complementar a concessão de suspensão da exigibilidade do crédito por meio de decisão judicial.

Ademais, ainda quanto ao regramento complementar-constitucional do tema, não só a instituição de uma causa de suspensão do crédito tributário é matéria de lei em sentido formal e material, mas, também, a interpretação da lei que concede o benefício fiscal há de ser interpretada literalmente ou restritivamente, nos termos do art. 111 do CTN:

\footnotetext{
Art. 111. Interpreta-se literalmente a legislação tributária que disponha sobre:

I - suspensão ou exclusão do crédito tributário;

II - outorga de isenção;

III - dispensa do cumprimento de obrigações tributárias acessórias.
}

\footnotetext{
${ }^{46}$ ATALIBA, Geraldo. Hipótese de Incidência Tributária. $6^{\mathrm{a}}$ edição. São Paulo: Malheiros, 2006, p. 24.
} 
Os dispositivos citados demonstram uma clara opção legislativa pela segurança jurídica no Direito Tributário, levando em conta a particular e delicada condição da relação jurídicotributária. Essa ponderação deve ser levada em conta pelo juiz na decisão do caso concreto. Por esse motivo, não cabe, ao Poder Judiciário, a de tutela que defira a suspensão da exigibilidade do crédito tributário, sob o fundamento do impacto econômico causado pelo COVID-19 sem que, para tanto, haja uma lei específica sobre o assunto.

Poder-se-ia, neste ponto, ainda, questionar acerca da eventual incidência direta de princípios constitucionais sobre o caso. Um dos fundamentos que são veiculados nas ações judiciais por meio das quais se pretende a suspensão da exigibilidade dos tributos na pandemia é de que o pagamento dos débitos fiscais comprometeria a própria continuidade da atividade da empresa.

Do ponto de vista fático, se poderia comprovar que o contribuinte exerce uma daquelas atividades impactadas diretamente pelo COVID-19 e que, por isso, teria verdadeiramente problemas de caixa para cumprir suas obrigações, havendo relação de causalidade direta entre o impacto da pandemia e a sua continuidade empresarial.

Contudo, em que pese a relevância do fundamento e sua veracidade, o fato é que ainda são não seria possível ao Poder Judiciário fazer incidir uma norma constitucional, pelo princípio da preservação da empresa ou da liberdade da atividade econômica, porque o legislador não adensou necessariamente esses princípios por meio de uma lei, para dar tratamento específico aos contribuintes que tiveram suas atividades impactadas.

Essa parece ser o entendimento do Supremo Tribunal Federal sobre o assunto. Embora tratando sobre tema especificamente diverso - qual seja, dedução fiscal a míngua de lei -, o Tribunal tem jurisprudência pacífica no sentido de que não cabe ao Poder Judiciário, sob o fundamento do princípio da isonomia, conceder benefício fiscal sem lei. Nesse sentido:

Ementa: TRIBUTÁRIO. AGRAVO REGIMENTAL NO RECURSO EXTRAORDINÁRIO. IMPOSTO DE RENDA PESSOA FÍSICA. LEGISLAÇÃO QUE ESTABELECE LIMITES À DEDUÇÃO DE GASTOS COM EDUCAÇÃO. CONSTITUCIONALIDADE. IMPOSSIBILIDADE DE O PODER JUDICIÁRIO ATUAR COMO LEGISLADOR POSITIVO. PRECEDENTES. 1. A jurisprudência do STF é no sentido de que não pode o Poder Judiciário estabelecer isenções tributárias, redução de impostos ou deduções não previstas em lei, ante a impossibilidade de atuar como legislador positivo. 2. Assim, não é possível ampliar os limites estabelecidos em lei para a dedução, da base de cálculo do IRPF, de gastos com educação (AI 724.817-AgR, rel. Min. Dias Toffoli, Primeira Turma, DJe de 09- 
03-2012; e RE 603.060-AgR, rel. Min. Cármen Lúcia, Primeira Turma, DJe de 0303-2011). 3. Agravo regimental a que se nega provimento.

(RE 606179 AgR, Relator(a): Min. TEORI ZAVASCKI, Segunda Turma, julgado em 21/05/2013, ACÓRDÃO ELETRÔNICO DJe-104 DIVULG 03-06-2013 PUBLIC 04-06-2013)

De fato, as questões já enfrentadas pelo STF são especificamente diversas, mas são de mesma categoria, isto é, a possibilidade de o Poder Judiciário conceder benefício fiscal sem lei, para fazer valer um princípio constitucional. Nesse cenário, é possível fazer a associação entre os fatos, levando-se à mesma conclusão do STF, e concluindo-se que os efeitos gerados pela COVID-19 não são juridicamente válidos para justificar categorizar o fato como uma causa de suspensão do crédito tributário.

\section{CONCLUSÃO}

O Poder Judiciário está constrito a limitações políticas, fáticas e jurídicas. Por outro lado, o Poder Legislativo e o Poder Executivo possuem atividades de planejamento e, para tanto, estão munidos de corpo especializado para apreender a complexidade dos fatos da realidade e, a partir de estudos, podem produzir instrumentos normativos gerais que permitam o tratamento adequado do tema, levando ainda em consideração as diversas situações particulares das centenas de modalidades de contribuintes.

O Poder Judiciário não tem estrutura própria para captar as complexidades que emanam do fato de uma maneira completa. É certo que medidas legislativas, como a universalização de instrumentos como o amicus curiae, se prestam a reduzir essa debilidade técnica, mas a decisão deve respeitar os contornos do caso concreto, não sendo possível proferir uma decisão quando o caso merece um tratamento sistêmico, que atenda a todas as particularidades dos casos concretos.

Os efeitos até então causados e aqueles que ainda serão causados pela epidemia da COVID-19 são complexos e inconclusivos, até mesmo para a ciência especializada. Além do mais, pela novidade da doença, não há estudos suficientes sobre o assunto, de forma que não é 
tema completamente mapeado. Nesse caso, o Poder Judiciário, com mais razão, deve ceder passo ao tratamento sistemático a ser dado pelo Poder Legislativo.

As ações que buscam, no Poder Judiciário, soluções para os próprios problemas de fluxo de caixa gerados pela redução drástica da oferta e da demanda devem ser analisadas com parcimônia, ante a ausência de tratamento legislativo que garanta uma causa de suspensão do crédito tributário sob o fundamento dos efeitos causadas pela pandemia do vírus COVID-19.

As leis editadas antes da pandemia tiveram seus próprios fundamentos e finalidades, mas no cenário atual, ante uma crise causada sem precedentes, é impossível encontrar similitude fática que justifique sua aplicação atualmente pelo Poder Judiciário.

O Poder Judiciário, por sua vez, encontra limitações constitucionais e operacionais para tratar do tema de maneira criativa ou mesmo por associação, mediante o uso de métodos integrativos do direito, como a analogia.

O tratamento constitucional-complementar sobre as causas de suspensão do crédito tributário é no sentido de que cabe somente ao Poder Legislativo a concessão de benefícios fiscais, em particular uma causa de suspensão do crédito tributário. Além do mais, o STF, em tema correlato, não admite que o juiz conceda benefícios fiscais sob o fundamento de incidência direta de princípio constitucional.

Nessa ordem de ideias, do ponto de vista político, fático e jurídico, exsurge a necessidade do Poder Judiciário exercer sua autocontenção, respeitando os limites do Estado de Direito e em particular o regime jurídico estabelecido no sentido claro da impossibilidade de conceder benefícios fiscais sem lei que os estabeleça.

Em tempos de incertezas científicas e de crise generalizada, cabe ao Poder Judiciário cumprir com mais rigor os ditames constitucionais - e não intensificar a insegurança jurídica para que seja evitado uma intolerável troca de funções institucionais, sendo esta uma forma mais segura para preservar o próprio Estado de Direito, cuja ideia permanecerá mesmo após mitigados ou ultrapassados - assim se espera - os efeitos da pandemia gerados pelo COVID19. 


\section{BIBLIOGRAFIA}

ATALIBA, Geraldo. Hipótese de Incidência Tributária. 6a edição. São Paulo: Malheiros, 2006.

BALEEIRO, Aliomar. Direito Tributário Brasileiro. 11ª edição. Rio de Janeiro: Forense, 2007,

BECHO, Renato Lopes. Considerações sobre dados extrajurídicos que podem estar influenciando os julgamentos tributários. Revista Brasileira a Advocacia, São Paulo, ano 3, n. 8, p. 156, jan./mar. 2018.

BEGANTON, Frankie, BOUGOUIN, Wulfran, DERKENNE, Clément, FRATTINI, Benoit, JOST, Daniel, JOUVEN, Xavier, KARAM, Nicole, LAFONT, Antoine, MARIJON, Eloi, PERROT, David, SHARIFZADEHGAN, Ardalan, WALDMANN, Victor. Out-of-hospital cardiac arrest during the COVID-19 pandemic in Paris, France: a population-based, observational study. Disponível em https://www.thelancet.com/pdfs/journals/lanpub/PIIS2468-2667(20)30117-1.pdf. Acessado em $28 / 05 / 2020$.

BRASIL. Constituição da República Federativa do Brasil de 1988. Disponível em http://www.planalto.gov.br/ccivil_03/constituicao/constituicao.htm. Acesso em 01/06/2020.

BRASIL. Lei $\mathrm{n}^{\mathrm{o}}$ 5.172, de 25 de outubro de 1966. Disponível em http://www.planalto.gov.br/ccivil_03/leis/15172.htm. Acesso em 01/06/2020.

BRASIL. Lei $\mathrm{n}^{\mathrm{o}}$ 13.105, de 16 de março de 2015. Disponível em http://www.planalto.gov.br/ccivil_03/_ato2015-2018/2015/lei/113105.htm. Acesso em 01/06/2020.

BRASIL. Instituto Brasileiro de Geografia e Estatística - IBGE. Pesquisa Nacional por Amostra de Domicílios Contínua - PNAD Contínua. Disponível em ftp://ftp.ibge.gov.br/Trabalho_e_Rendimento/Pesquisa_Nacional_por_Amostra_de_Domicilio s_continua/Trimestral/Tabelas/2020/2020_1_trimestre/pnadc_202001_tabelas_brasil.zip. Acessado em 28/05/2020.

BRASIL. Instituto Brasileiro de Geografia e Estatística - IBGE. Sistema de Contas Nacionais Trimestrais - SCNT. Disponível em https://www.ibge.gov.br/estatisticas/economicas/contasnacionais/9300-contas-nacionais-

trimestrais.html?=\&t=destaques\&utm_source=landing\&utm_medium=explica\&utm_campaig n=pib\#evolucao-taxa. Acessado em 31/05/2020.

BRASIL. Supremo Tribunal Federal. 2. T. Agravo Regimental no Recurso Extraordinário n. 606.179-SP. Rel. Min. Teori Zavascki. Un. J. 21.05.2103. DJe n. 104, de 04.06/2013.

BUENO, Cassio Scarpinella. Amicus Curiae no Processo Civil Brasileiro: um terceiro enigmático. $3^{\mathrm{a}}$ edição. São Paulo: Saraiva, 2012.

DEVLIN, Patrick Arthur. Judges and Lawmakers. In Modern Law Review, 39, 1976. 
CAPPELLETTI, Mauro. Juízes legisladores? Porto Alegre: Sergio Antonio Fabris, 1993.

CONRADO, Paulo Cesar. Processo Tributário. 2a edição. São Paulo: Quartier Latin, 2007.

COSTA, Regina Helena. Curso de Direito Tributário. $8^{\text {a }}$ edição. São Paulo: Saraiva, 2018.

ORGANIZAÇÃO DAS NAÇÕES UNIDAS. Rolling updates on coronavirus disease (COVID19). Disponível em https://www.who.int/emergencies/diseases/novel-coronavirus2019/events-as-they-happen. Acessado em 29/05/2020.

ORGANIZAÇÃO DAS NAÇÕES UNIDAS. Considerations in adjusting public health and social measures in the context of COVID-19. Disponível em https://apps.who.int/iris/bitstream/handle/10665/331773/WHO-2019-nCoV-

Adjusting_PH_measures-2020.1-eng.pdf. Acessado em 01/06/2020.

ORGANIZAÇÃO DAS NAÇÕES UNIDAS. WHO Coronavirus Disease (COVID-19) Dashboard, Disponível em https://covid19.who.int/. Acessado em 29/05/2020.

POSNER, Richard Allen. Reflections on judging. Cambridge: Harvard University Press, 2013.

POSNER, Richard Allen. Law, pragmatism and democracy. Cambridge: Harvard University Press, 2003.

Data de Submissão: 08/06/2020

Data de Aceite: 03/08/2020 